\title{
Jurassic hazards to coral growth
}

SIR - The only period when substantial coral growth occurred in Britain after the Palaeozoic was at the beginning of the Upper Jurassic, during the Upper Oxfordian (Corallian). Small coral patches are found along much of the outcrop in England and the geology of the coral-bearing units has been studied by Arkell $(1928,1933,1935)$ and other authors. At Shellingford Cross Roads Quarry (Nat. Grid Ref. SU 327941, Fig. 1) coral growth was interrupted by penecontemporaneous erosion and smothering and influxes of clay of volcanic origin.

The coralliferous unit at Shellingford is lenticular, up to $2 \mathrm{~m}$ thick, and formed principally of autochthonous branching Thecosmilia associated with massive Thamnasteria and Isastrea. The lower part comprises branching colonies whilst the upper is mainly of massive corals. Growth of Thecosmilia was intermittently and locally interrupted at three main levels by deposition of discrete biosparite lenses, and by muddy sedimentation which smothered the calices. The mud occurs as lenses, 0-6 cm thick, now composed of about $60-70 \%$ clay together with some silt and sand-sized quartz grains, coral and shell debris.

The mineralogy of the clay from these seams was determined by X-ray diffraction using nickel-filtered $\mathrm{Cu}-\mathrm{K} \alpha$ radiation at $35 \mathrm{kV} / 55 \mathrm{~mA}$. The $<2 \mu \mathrm{m}$ fractions were separated by sedimentation after disaggregation of the original samples, and mounted on ceramic tiles by vacuum filtration. Identification of clay mineral phases involved the standard pretreatment of glycollation and heating to $400^{\circ} \mathrm{C}$.

Semi-quantitative estimates of the relative amounts of clay minerals were calculated using the glycollated $X$-ray trace, and an expression of the ratio of smectite to illite was obtained by comparing the area of the $17 \AA$ peak to that of the $10 \AA$ peak. The results of these analyses show that smectite is dominant over subsidiary illite. Samples from the clays associated with corals from Shellingford and elsewhere in Oxfordshire, Yorkshire, and in the Cambridge area indicate a smectite content of about 88-98\% and $2-12 \%$ illite and up to $2 \%$ kaolinite. The insoluble clay fraction from the coral biomicrite shows a similar clay mineral composition. The origin of such pure smectite in the Jurassic has been discussed by Hallam \& Sellwood (1968) and it is believed that these seams resulted from the alteration of contemporary volcanic material. Thus, besides their ecological significance, these sediments provide evidence for Upper Jurassic volcanism. Kent (1975) and Hallam \& Sellwood (1976) reviewed evidence for volcanicity in the North Sea associated with rifting but did not specifically identify a late Oxfordian episode.

There are several records of corals and coral reefs under ecological stress. Events of mechanical destruction during tropical storms and effects of clay sedimentation on coral growth were reviewed by Stoddart (1969) and lava flows frequently interrupt growth of hermatypic corals in Hawaii (Grigg \& Maragos, 1974).

There is, however, no modern record of actual volcanic ash smothering. Scoffin (1971) recorded the occurrence of two bentonite bands and thin shale seams in the Wenlock reefs of Shropshire. These generally correlate with indentations in the margins of the reefs suggesting that the lateral profiles were governed by the rate of clay sedimentation. Hubbard \& Pocock (1972) recorded abrupt termination of cerioid coral forms from the Carboniferous of NW Ireland beneath an overlying shale parting and $\mathrm{Dr}$ G. Warner saw (pers. comm.) mud blanketing in a bay on the Gulf of Paria, Trinidad, where he noted partial damage of Scolemia due to silting. 


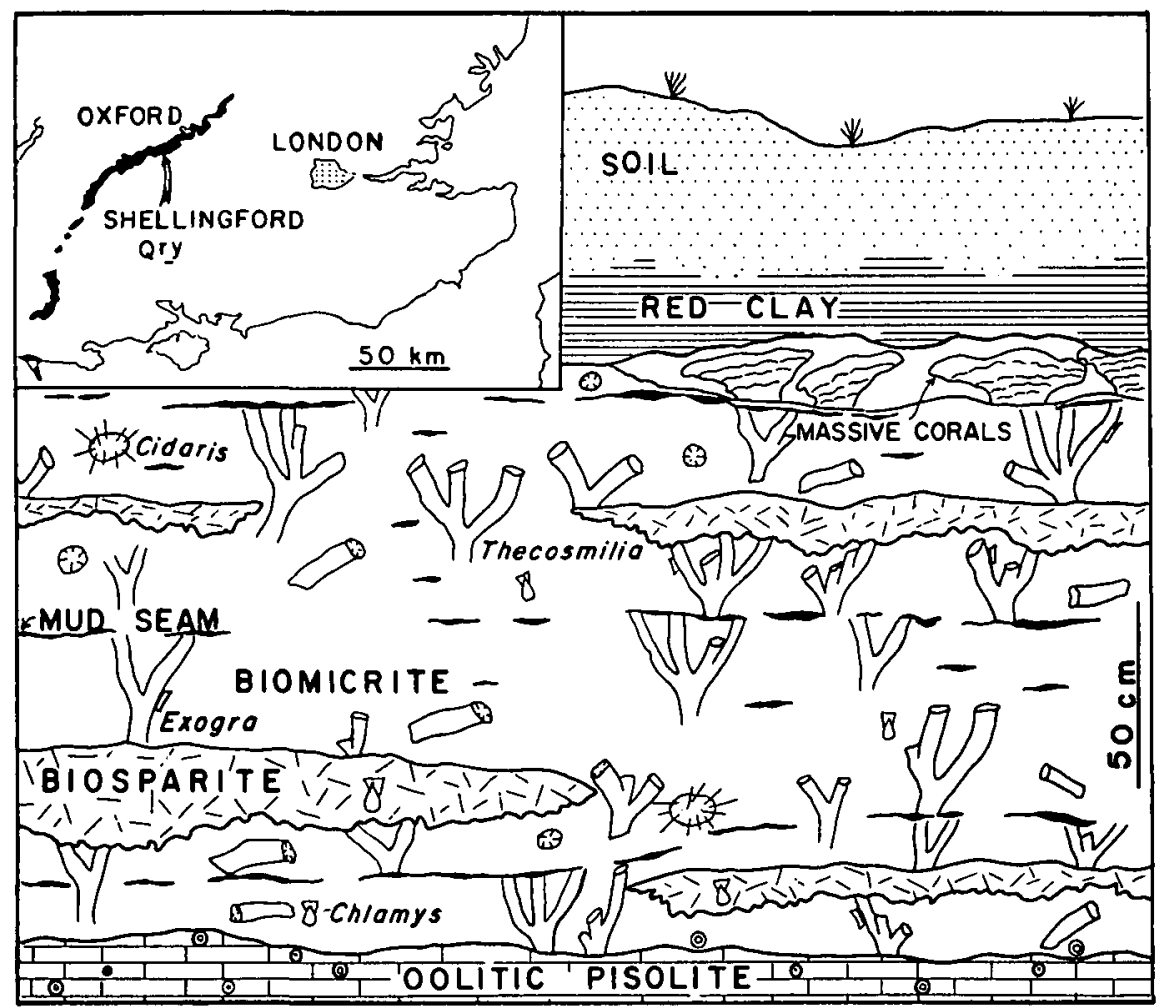

Figure 1. Diagrammatic representation of the coralliferous unit at Shellingford Cross Roads Quarry. Inset, outcrop of the Corallian (in black).

\section{References}

Arkell, W. J. 1928. Aspects of the ecology of certain fossil coral reefs. J. Ecology 16, $134-49$.

Arkell, W. J. 1933. The Jurassic System in Great Britain. Clarendon Press, Oxford 681 pp.

Arkell, W. J. 1935. On the nature, origin and climatic significance of the coral reefs near Oxford. Q. Jl geol. Soc. 91, 77-110.

Grigg, R. W. \& Maragos, J. E. 1974. Recolonization of hermatypic corals on submerged lava flows in Hawaii. Ecology 55, 387-95.

Hallam, A. \& Sellwood, B. W. 1968. Origin of Fuller's earth in the Mesozoic of Southern England. Nature, Lond. 220, 1193-5.

Hallam, A. \& Sellwood, B. W. 1976. Middle Mesozoic sedimentation in relation to tectonics in the British area. J. Geol. 48.

Hubbard, J. A. E. B. \& Pocock, Y. P. 1972. Sediment rejection by recent scleractinian corals: a key to palaeo-environmental reconstruction. Geol. Rdsch. 61, 598-626.

Kent, P. E. 1975. Review of North Sea Basin development. J. geol. Soc. Lond. 131, 435-69.

Stoddart, D. R. 1969. Ecology and morphology of recent coral reefs. Biol. Rev. 44, 433-98.

Scoffin, T. P. 1971. The conditions of growth of the Wenlock reefs of Shropshire. Sedimentology 17, 173-219.

Sedimentology Research Laboratory

O. E. ALI

Department of Geology

University of Reading

U.K.

2nd July, 1976. 